\title{
Performance and biometry of the gastrointestinal tract in growing Japanese quails fed bee pollen
}

\section{Desempenho e biometria do trato gastrointestinal de codornas japonesas em crescimento alimentadas com pólen apícola}

\section{Lorena Mari Sanches ${ }^{1}$; Cinthia Eyng 2*; Rodrigo Garófallo Garcia3; Jomara Broch; Felipe Potenza Campos ${ }^{5}$; Karine Isabela Tenório ${ }^{6}$}

\section{Highlights}

We studied the effects of bee pollen on growing quails diets.

Bee polen was not able to produce changes in the performance.

The biometry of digestive organs was not alter by dietary inclusion of bee pollen.

The inclusion of bee polen linear reduced the relative weight of small intestine.

The bee pollen did not show an enhanced performance capacity.

\begin{abstract}
The aim of this study was to evaluate the effects of different levels of bee pollen in the diet of growing Japanese quails on productive performance, relative weight of the gastrointestinal organs and length of small and large intestines. A total of 650 one-day-old female Japanese quails were distributed in a completely randomized design with five treatments according to the dietary levels of bee pollen (0.0, 0.4, $0.8,1.2$, and $1.6 \%)$, five replicates, and 26 birds per experimental unit. At the end of the experimental period (35 days of age), the performance and relative weight of the gastrointestinal organs and length of small and large intestines were evaluated. The dietary inclusion of bee pollen did not influence $(P>0.05)$ performance, relative weight of proventriculus, gizzard, pancreas, liver, and large intestine, as well as the length of small and large intestines. However, a linear reduction $(P<0.05)$ was observed in the relative weight of small intestine as dietary bee pollen levels increased. The inclusion of bee pollen from 0.4 to $1.6 \%$ in the diet of growing

1 PhD Student of Postgraduate Program in Zootechnics, Faculty of Agricultural Sciences, Federal University of Grande Dourados, UFGD, Dourados, MS, Brazil. E-mail: lo.orena@hotmail.com

2 Prof., Dr., Postgraduate Program in Zootechnics, Western Paraná State University, UNIOESTE, Marechal Cândido Rondon, PR, Brazil. E-mail: cinthiaeyng@hotmail.com

${ }^{3}$ Prof. Dr., Postgraduate Program in Zootechnics, UFGD, Dourados, MS, Brazil. E-mail: rodrigogarcia@ufgd.edu.br

4 Dr. in Zootechnics, UNIOESTE, Marechal Cândido Rondon, PR, Brazil. E-mail: brochjomara@yahoo.com.br

${ }^{5}$ Undergraduate student of Zootechnics, UNIOESTE, Marechal Cândido Rondon, PR, Brazil. E-mail: felipe.potenza. campos@gmail.com

${ }^{6}$ Master Student of Postgraduate Program in Zootechnics, UNIOESTE, Marechal Cândido Rondon, PR, Brazil. E-mail: karinetenorio@gmail.com

* Author for correspondence
\end{abstract}

Received: June 01, 2020 - Approved: Jan. 07, 2021 
Japanese quails did neither improve productive performance nor alter the biometry of digestive organs.

Key words: Antimicrobial activity. Coturnix coturnix japonica. Digestive organs. Natural additive.

\section{Resumo}

O objetivo deste estudo foi avaliar os efeitos de diferentes níveis de pólen apícola nas dietas de codornas japonesas em crescimento sobre o desempenho produtivo, peso relativo dos órgãos do trato gastrointestinal e comprimento do intestino delgado e grosso. Um total de 650 codornas japonesas, fêmeas, de um dia de idade, foram distribuídas em um delineamento inteiramente casualizado com cinco tratamentos de acordo com os níveis dietéticos do pólen apícola $(0,0 ; 0,4 ; 0,8 ; 1,2$ e 1,6\%), cinco repetições e 26 aves por unidade experimental. Ao final do período experimental (35 dias de idade), o desempenho e o peso relativo dos órgãos do trato gastrointestinal e o comprimento do intestino delgado e grosso foram avaliados. A inclusão dietética de pólen de abelha não influenciou $(P>0,05)$ o desempenho, peso relativo do proventrículo, moela, pâncreas, fígado e intestino grosso, bem como o comprimento do intestino delgado e intestino grosso. Entretanto, uma redução linear $(P<0,05)$ foi observada no peso relativo do intestino delgado de acordo com o aumento dos níveis de pólen apícola. A inclusão dietética de 0,4 a 1,6\% de pólen apícola para codornas japonesas em crescimento não melhorou o desempenho produtivo e não alterou a biometria dos órgãos digestivos.

Palavras-chave: Aditivo natural. Atividade antimicrobiana. Coturnix coturnix japonica. Órgãos digestivos.

Antibiotics as a growth promoter (AGP) have been used for years as a prophylactic method to control disease in poultry, ensuring better productive rates. Although the mechanisms of action are still being investigated, the enhanced performance has been related to improvements in the gastrointestinal tract health, with a consequent increase in nutrient use efficiency (Stanley, Hughes, Geier, \& Moore, 2016).

The use of antimicrobial additives at sub-therapeutic levels has been widely discussed because its use for extended periods may favor the emergence of bacterial cells resistant to numerous active principles, representing a risk to human health (Marshall \& Levy, 2011). Therefore, European Union countries banned the use of AGP in the animal diets in 2006 (Babaei, Rahimi, Torshizi, Tahmasebi, \& Miran, 2016). As a consequence, researchers seek alternatives to reduce or eliminate the prophylactic use of antimicrobials in the poultry industry.

In the search for products that do not present a risk of bacterial resistance and that do not leave residues in the product, the use of natural substances with antimicrobial characteristics stands out. Many natural substances used as alternatives to antibiotics in animal diets express positive effects on performance, intestinal health, and the immune system (Abdelnour, Abd El-Hack, Alagawany, Farag, \& Elnesr, 2019).

In this regard, bee pollen is widely used as a natural supplement due to its antifungal, antimicrobial, antiviral, anti-inflammatory, immunostimulant, anticancer, and analgesic activities (Costa, Morgano, Ferreira, \& Milani, 2017). The bioactive substances in bee pollen responsible for its pharmacological actions are phenolic compounds and carotenoids (Zuluaga et al., 2016). Besides, the phenolic compounds 
in bee pollen can delay the proliferation of pathogenic microorganisms (Mohdaly, Mahmoud, Roby, Smetanska, \& Ramadan, 2015), helping to maintain intestinal health and favoring the digestive and absorptive processes of the animal. Several studies have investigated the use of bee pollen in bird diets. Farag and El-Rayes (2016) observed an improvement in performance, carcass yield, and immunity of broilers receiving $0.6 \%$ of bee pollen. Babaei et al. (2016), evaluating diets containing bee pollen ( 0.1 and $0.5 \%)$, observed that the addition of pollen could be beneficial in improving quail performance.

Based on this information, we hypothesized that dietary inclusion of bee pollen can favor the gut health of growing quails allowing a better productive performance. Therefore, we evaluated the effects of different levels of bee pollen in the diet of growing Japanese quails on the performance and relative weight of gastrointestinal organs.

The trial was conducted at the Poultry Research Center of the Federal University of Grande Dourados, Brazil. The quails were raised according to the ethical principles for animal experimentation established by the Brazilian Society of Laboratory Animal Science and the National Council for the Control of Animal Experimentation (CONCEA). A total of 650 1-day-old female Japanese quails were distributed in a completely randomized design with five treatments $(0.0,0.4,0.8,1.2$, and $1.6 \%$ of bee pollen - $100 \%$ pure), five replicates, and 26 birds per experimental unit (EU). The poultry house was divided into floor pens, measuring $2.12 \mathrm{~m}^{2}$ each, provided with new pine wood shavings, and each EU had access to a tubular feeder, and bell drinkers. To control the internal temperature, the facility was equipped with a negative pressure system and infrared heating lamps. The lighting program consisted of continuous $23 \mathrm{~h}$ light and $1 \mathrm{~h}$ of darkness (30 lux light intensity) throughout the whole experimental period.

The quails were fed the experimental diets and water ad libitum. The experimental diets were formulated based on corn and soybean meal, according to nutritional requirements for Japanese quails recommended by Rostagno et al. (2011). The nutritional requirements for diet formulation were as follows: apparent metabolizable energy $2,800 \mathrm{kcal} / \mathrm{kg}$, crude protein $19.94 \%$, calcium $3.09 \%$, available phosphorus $0.323 \%$, sodium $0.15 \%$, digestible methionine + cysteine $0.88 \%$, digestible lysine $1.08 \%$, and digestible threonine $0.68 \%$. The bee pollen used in this study was collected in several areas of the state of Paraná, Brazil, and obtained from a commercial supplier (Apiário Diamante Comercial Exportadora Ltda, Maringá, Paraná, Brazil). Prior to use in the diets, it was crushed and kept at 2 to $8^{\circ} \mathrm{C}$; it was added to the diets as a replacement of inert (kaolin).

On the 35th day of age, the quails and leftovers were weighed to evaluate the average feed intake, weight gain, and feed conversion ratio for each EU. Mortality was observed daily to correct the average feed intake and feed conversion.

At the end of the experimental period, five birds per treatment were randomly selected considering the average weight (average $\pm 5 \%$ ) of replicate and slaughtered by cervical dislocation to determine the relative weight (\% of live weight) of the gastrointestinal organs (proventriculus, gizzard, small intestine, large intestine, pancreas and liver) and length of the small and large intestines. The organs were cleaned with physiologic saline solution, dried with filter paper, and weighed. 
The obtained data were submitted to analysis of variance and polynomial regression at $5 \%$ significance using the SAEG software (SAEG, 2007).

Although the literature indicates that phenolic compounds in bee pollen have antimicrobial and immunostimulatory actions (Costa et al., 2017), which may result in improvements in performance, no influence of bee pollen levels was observed on quail performance (Table 1). No differences associated with bee pollen levels were found $(P>0.05)$ for the relative weight $(\%)$ of proventriculus, gizzard, pancreas, liver, and large intestine, as well as the length of the small and large intestines (Table 2). However, a linear reduction $(P<0.05)$ was observed in the relative weight of the small intestine with increasing levels of dietary bee pollen (Table 2).

After ingestion, phenolic compounds may undergo enzymatic degradation that alters its composition, bioavailability, and absorption
(Juániz et al., 2016). Complementary, the metabolism of intestinal microbiota may cause these changes, and therefore, the biological results should not be attributed only to the original compounds contained in the feed but also to its metabolites (Duda-Chodak, Tarko, Satora, \& Sroka, 2015). According to Hosseini, Vaiki Azghandi, Ahani and Nourmohammadi (2016), bee pollen can be used as a feed additive with a protective effect against the effects of heat stress in broiler chickens. In the same way, Tatlı Seven, Sur Arslan, Seven and Gökçe (2016) suggested that bee pollen supplementation had potential protective activity on lipid peroxidation and tissue fatty acid composition of quails reared under high stocking densities. The contradictory results in the literature may indicate that the effect of this additive can be more pronounced when birds are raised under stress conditions, since animals under optimal environmental conditions may not respond to growth-promoting supplements.

\section{Table 1}

Weight gain, feed intake, and feed:gain of growing Japanese quails fed with different levels of bee polen

\begin{tabular}{|cccc|}
\hline Levels of bee polen (\%) & Weight gain $(\mathrm{g})$ & Feed intake $(\mathrm{g})$ & Feed:Gain \\
\hline 0.0 & 120.98 & 411.76 & 3.40 \\
\hline .4 & 115.75 & 420.12 & 3.63 \\
\hline 0.8 & 118.44 & 433.48 & 3.66 \\
\hline 1.2 & 118.39 & 441.34 & 3.72 \\
\hline 1.6 & 121.91 & 456.08 & 3.75 \\
\hline P Anova & 0.383 & 0.523 & 0.530 \\
\hline P Reg Linear & 0.540 & 0.080 & 0.120 \\
\hline P Reg Quadratic & 0.100 & 0.920 & 0.520 \\
\hline CV (\%) & 4.34 & 9.91 & 9.38 \\
\hline
\end{tabular}

$\mathrm{CV}=$ coefficient of variatiodun. 
Table 2

Relative weight (\%) of gastrointestinal organs and length of small and large intestine $(\mathrm{cm})$ of Japanese quails at 35 days of age fed with different levels of bee polen

\begin{tabular}{ccccccccc|}
$\begin{array}{c}\text { Levels of } \\
\text { bee polen } \\
(\%)\end{array}$ & Proventriculus & Gizzard & Pancreas & Liver & $\begin{array}{c}\text { Small } \\
\text { intestine }\end{array}$ & $\begin{array}{c}\text { Large } \\
\text { intestine }\end{array}$ & $\begin{array}{c}\text { Small } \\
\text { intestine } \\
\text { length }\end{array}$ & $\begin{array}{c}\text { Large } \\
\text { intestine } \\
\text { length }\end{array}$ \\
\hline 0.0 & 0.474 & 2.246 & 0.282 & 2.288 & 3.018 & 1.257 & 48.280 & 19.920 \\
\hline 0.4 & 0.444 & 2.673 & 0.285 & 2.355 & 2.474 & 1.072 & 46.200 & 16.560 \\
\hline 0.8 & 0.451 & 2.446 & 0.268 & 2.282 & 2.419 & 1.115 & 45.700 & 18.400 \\
\hline 1.2 & 0.436 & 2.670 & 0.245 & 2.334 & 2.480 & 1.138 & 46.080 & 17.720 \\
\hline 1.6 & 0.405 & 2.515 & 0.266 & 2.263 & 2.462 & 1.276 & 46.460 & 18.920 \\
\hline P Anova & 0.729 & 0.278 & 0.603 & 0.998 & 0.089 & 0.764 & 0.917 & 0.576 \\
\hline $\begin{array}{c}\text { P Reg } \\
\text { Linear }\end{array}$ & 0.203 & 0.278 & 0.243 & 0.924 & 0.0451 & 0.808 & 0.577 & 0.858 \\
\hline $\begin{array}{c}\text { P Reg } \\
\text { Quadratic }\end{array}$ & 0.842 & 0.222 & 0.679 & 0.864 & 0.071 & 0.222 & 0.468 & 0.243 \\
\hline CV (\%) & 17.84 & 13.48 & 15.73 & 22.55 & 14.25 & 25.34 & 10.08 & 17.94 \\
\hline
\end{tabular}

${ }^{1} Y=2.7918532+0.27629635 x\left(R^{2}=0.48\right) . C V=$ coefficient of variation.

Our results are in accordance with those reported by Hosseini et al. (2016), who found no impact of bee pollen on pancreas, liver, gizzard, and relative intestine weight. Also, Canogullari, Baylan, Sahlnler and Sahin (2009) indicated that the addition of bee pollen did not result in any differences in carcass, liver, and gizzard yield of the quails. According to Miles, Butcher, Henry and Littell (2006), the use of antimicrobial substances influences the weight of the gastrointestinal tract, leading to a reduction in its weight. The reduction in the relative weight of the small intestine may be related to the antibacterial activity of bee pollen, attributed to the presence of phenolic compounds. Phenolic compounds in bee pollen have been associated with the prevention of the proliferation of pathogenic microorganisms (Mohdaly et al., 2015), avoiding lesions and inflammation in the intestinal epithelium, reducing its thickness and, consequently, its weight. Considering that this reduction is related to the antibacterial action of bee pollen, however the microbiological control was insufficient to improve the performance of birds.

The inclusion of bee pollen from 0.4 to $1.6 \%$ in the diet of growing Japanese quails did neither improve productive performance nor alter the biometry of digestive organs.

\section{Acknowledgments}

The authors are grateful to the Brazilian institutions and research agencies CAPES and CNPq.

\section{Conflict of interest declaration}

The authors declared no conflict of interest. 


\section{References}

Abdelnour, S. A., Abd El Hack, M. E., Alagawany, M., Farag, M. R., \& Elnesr, S. S. (2019). Beneficial impacts of bee pollen in animal production, reproduction and health. Journal of Animal Physiology and Animal Nutrition, 103(2), 477-484. doi: 10.1111/ jpn.13049

Babaei, S., Rahimi, S., Torshizi, M. A. K., Tahmasebi, G., \& Miran, S. N. K. (2016). Effects of propolis, royal jelly, honey and bee pollen on growth performance and imune system of Japanese quails. Veterinary Research Forum, 7(1), 13-20. PMCID:PMC4867032

Canogullari, S., Baylan, M., Sahinler, N., \& Sahin, A. (2009). Effects of propolis and pollen supplementations on growth performance and body components of Japanese quails (Coturnix coturnix japonica). Archiv Für Geflügelkunde, 73(3), 173-178.

Costa, M. C. A., Morgano, A. M., Ferreira, M. M. C., \& Milani, R. F. (2017). Analysis of bee pollen constituents from differents Brazilian regions: quantification by NIR spectroscopy and PLS regression. Food Science Technology, 80, 76-83. doi: 10. 1016/j.Iwt.2017.02.003

Duda-Chodak, A., Tarko, T., Satora, P., \& Sroka, P. (2015). Interaction of dietary compounds, especially polyphenols, with the intestinal microbiota: a review. European Journal of Nutrition, 54(3), 325-341. doi: 10.1007/ s00394-015-0852-y

Farag, S. A., \&El-Rayes, T. K. (2016). Effect of beepollen supplementation on performance, carcass traits and blood parameters of broiler chickens. Asian Journal of Animal and Veterinary Advances, 11(3), 168-177. doi: 10.3923/ajava.2016.168.177

Hosseini, S. M., Vakili Azghandi, M., Ahani, S., \& Nourmohammadi, R. (2016). Effect of bee pollen and propolis (bee glue) on growth performance and biomarkers of heat stress in broiler chickens reared under high ambient temperature. Journal of Animal and Feed Sciences, 25(1), 45-51. doi: 10.22358/jafs/ 65586/2016

Juániz, I., Ludwig, I. A., Bresciani, L., Dall'Asta, M., Mena, P., Del Rio, D.,... Peña, M-P. (2016). Catabolism of raw and cooked green pepper (Capsicum annuum) (poly) phenolic compounds after simulated gastrointestinal digestion and faecal fermentation. Journal of Functional Foods, 27, 201-213. doi: 10.1016/j.jff. 2016.09.006

Marshall, B. M., \& Levy, S. T. (2011). Food animals and antimicrobials: Impacts on human health. Clinical Microbiology Reviews, 24 (4), 718-733. doi: 10.1128/CMR.00002-11

Miles, R. D., Butcher, G. D., Henry, P. R., \& Littell, R. C. (2006). Effect of antibiotic growth promoters on broiler performance, intestinal growth parameters, and quantitative morphology. Poultry Science, 85(3), 476-485. doi: 10.1093/ps/85.3.476

Mohdaly, A. A. A., Mahmoud, A. A., Roby, M. H. H., Smetanska, I., \& Ramadan, M. F. (2015). Phenolic extract from propolis and bee pollen: composition, antioxidant and antibacterial activities. Journal of Food Biochemistry, 39(5), 538-547. doi: $10.1111 /$ jfbc. 12160

Rostagno, H. S., Albino, L. F. T., Donzele, J. L., Gomes, P. C., Oliveira, R. F., Lopes, D. C.,... Euclides, R. F. (2011). Tabelas brasileiras 
para aves e suínos: composição de alimentos e exigências nutricionais $(2 \mathrm{a}$ ed.). Viçosa, MG: UFV, Departamento de Zootecnia.

Stanley, D., Hughes, R. J., Geier, M. S., \& Moore, R. J. (2016). Bacteria within the gastrointestinal tract microbiota correlated with improved growth and feed conversion: challenges presented for the identification of performance enhancing probiotic bacteria. Frontiers in Microbiology, 7, 187. doi: 10. 3389/ fmicb.2016.00187

Tatı Seven, P., Sur Arslan, A., Seven, I., \& Gökçe, Z. (2016). The effects of dietary bee pollen on lipid peroxidation and fatty acids composition of Japanese quails (Coturnix coturnix japonica) meat under different stocking densities. Journal of Applied Animal Research, 44(1), 487-491. doi: 10. 1080/097121 19.2015.1091339

SAEG - Sistema para análises estatísticas. Universidade Federal de Viçosa (2007). Versão 9.1. Viçosa, UFV: Fundação Arthur Bernardes.

Zuluaga, M., Martínez, A., Fernández, J., LópezBaldó, J., Quiles, A., \& Rodrigo, D. (2016). Effect of high pressure processing on carotenoid and phenolic compounds, antioxidant capacity, and microbial counts of bee-pollen paste and bee-pollen-based beverage. Innovative Food Science \& Emerging Technologies, 37(Part A), 10-17. doi: 10.1016/j.ifset.2016.07.023 
